\title{
Kommentarer til artiklen »Betingelser for socialistisk fagforeningsarbejde
}

\author{
Kurt Aagaard Nielsen \\ Susanne Possing.
}

\section{Lidt om artiklens historiske baggrund}

Den seneste udvikling i kapitalismens krise har problematiseret den venstreintellektuelle bevægelses sædvanlige strategi-forståelse. Arbejdet er blevet »politiseret « og debatten om organiserings-problemet blevet skærpet. I denne situation kommer artiklen: »Betingelser for socialistisk fagforeningsarbejde «, af hvilken her bringes første del i dansk oversættelse, som et positivt bidrag til videreudvikling af diskussionen.

Generelt har man på den danske venstrefløj formuleret disse problemer alment som spørgsmål om at udvikle en revolutionær strategi overhovedet. Man har stillet problemet ud fra sin egen selvforståelse som revolutionært individ. Denne artikels fortjeneste består $\mathrm{i}$, at den forsøger at stille den intellektuelle venstrefløjs 'politiske problemer' med udgangspunkt i arbejderklassens historisk specifikke aktionsmuligheder og organisationsformer. Herved $\mathrm{g} \varnothing \mathrm{r}$ forfatterne det muligt at overskride den formulering af de venstreintellektuelles politiskorganisatoriske problemer, som herhjemme bl.a. er kommet til udtryk i den fiktive modstilling af »kapitallogik og klassekamp «. ${ }^{1}$

I denne kommentar, som vil diskutere fagforeningsartiklens væsentligste resultater, vil vi klargøre, hvorledes den bidrager til en sådan overskridelse. Vi behandler primært artiklen ud fra en teoretisk kritik af dens bestemmelser og konklusioner. Udgangspunkt og sigtepunkt for diskussionen er imidlertid problematikken om, hvordan man bestemmer grundlaget for de fælles teoretiske og politiske erfaringer, som udvikles blandt såvel intellektuelle som arbejdere på venstrefløjen. Netop af den grund er vi bevidste om begrænsningerne i en abstrakt kritik.

1. Se f.eks. Peter Madsens præsentation af og interview med Bernd Rabehl i politisk revy, nr. 256, 1974. 
I betragtning af artiklens positive tendens til at stille »de politiske problemer « historisk-konkret og i forhold til sigtepunktet med vores kritik, skal det derfor understreges at en fortsat almen-teoretisk behandling af problemer, hvis løsning $\mathrm{i}$ kraft af deres materielle specificitet ikke kan almengфres, må afvises.

Vi vil derfor også her kort redegøre for den særlige sammenhæng, som artiklen er blevet til i, for herigennem at advare læseren mod at overføre artiklens konklusioner uformidlet på den danske virkelighed. Imidlertid har det været vanskeligt at foretage andet end en relativt teoretisk kritik over for den her foreliggende første almene del af artiklen.

For det første vil vi henvise til den historiske fremstilling i artiklens anden del, som vil blive bragt i Kurasje nr. 12. Forfatterne fors $\emptyset$ ger her at give ansatserne til en aktuel analyse af forholdet mellem fagbevægelse og kapitaludvikling i Vesttyskland. Analysen som helhed er udarbejdet som led i en specifik diskussion inden for $»$ Sozialistisches Büro $\aleph^{2}$ om mulighederne for, at den faglige kamp vil kunne udvikle revolutionære positioner. Det er derfor vigtigt at holde dette i baghovedet, når bestemmelsen her af den fagforeningsmæssige organisering vurderes.

For det andet bør det fremhæves, hvorledes den vesttyske kapitalismes specifikke udviklingsbetingelser har haft konsekvenser for, hvilken udgangssituation arbejderklassen henholdsvis de venstreintellektuelle har stået i. I denne forbindelse mener vi, man må skelne mellem betingelserne for den politiske organisering af arbejderklassen respektive den intellektuelle venstrebevægelse:

Arbejderklassens organiseringsproblem. Den tyske fagbevægelse er i særlig grad karakteriseret ved, at den er et resultat af den økonomiske udvikling efter 2. Verdenskrig og som sådan opviser historisk relativt nye træk. Allerede umiddelbart efter krigens afslutning befæstedes den nuværende opdeling i den tyske fagbevægelse mellem bedriftsråd og fagforening ${ }^{3}$. Denne struktur blev dels påtvunget fagbevægelsen af de allierede besættelsesmagter, dels realiseret frivilligt som resultat af svækkelsen af arbejderklassen efter krigen, hvilket medførte, at man generelt forlod de oprindelige socialistiske positioner. (sml. Thesen des SB, s. 12). Med »Das Betriebsverfassungsgesetz« (lovgivning vedrørende bedriftsorganiseringen) fra 1952 styrkedes denne mulighed for en spaltning i fagbevægelsen. På den ene side skulle bedriftsrådene fungere som integrationsorganer i forholdet mellem arbejdere og virksomhedsledelse, på den anden side var fagforeningerne underlagt et strengt pragmatisk krav om interessereprasentation. (Disse to funktioner genfindes naturligvis også i den danske fagbevægelse, hvor de imidlertid ikke har været underlagt de samme udviklingsbetingelser som i Vesttyskland). For at illustrere konsekvenserne af disse særlige forhold, vil vi blot nævne, hvorledes fagforeningerne under »Wirtschaftswunder«-perioden

2. SB er en for danske forhold fremmed organisering af socialistiske studenter/akademikere og arbejdere. En god orientering om denne organisation fås i »Thesen des Sozialistischen Büros«, Offenbach, Februar 1975.

3. Jvf. Jürgen Klein, Hand in Hand gegen die Arbeiter, Verlag Association, 1974, s. $190 \mathrm{f}$. 
udadtil indskrænkede lønkampen til udelukkende at finde sted indenfor rammerne af generelle overenskomstforhandlinger. Indadtil i fagbevægelsen havde denne politik den funktion at begrænse medlemmernes indflydelse, eftersom de overenskomstmæssige resultater, som opnåedes, skabte en bred loyalitet blandt medlemmerne. Samtidig kunne fagforeningernes centralistiske organisationsstruktur udbygges. Denne tendens i fagbevægelsens udvikling understregedes nu yderligere gennem fagforeningernes karakteristiske bindinger: På den ene side måtte de repræsentere lønarbejdernes interesser som lønafhængige, og på den anden side måtte de - inden for rammerne af den »Konzertierte Aktion « - st $\varnothing t t e$ den socialdemokratiske regerings $\varnothing$ konomiske politik. Det er disse forhold, som udgør det materielle grundlag for den vesttyske fagbevægelses integration i kapitaludviklingen i form af et 'socialpartnerskab'.

Imidlertid forløb denne udvikling ikke uden gnidninger: Såvel i 50'erne som i 60'erne foretog mange bedriftsråd antikapitalistiske aktioner, som konsekvent blev undertrykt enten direkte gennem arbejdsretslige sanktioner eller indirekte på grund af SPDs harmoniseringspolitik. I 1969 indleder så Septemberstrejker$n^{4}$ den fase, hvor socialpartner-politikken for alvor kommer ud i en krise, og hvor modsætningsforholdet mellem fagforeningsledelse og medlemsbasis skærpes; fagforeningsledelsens repræsentationsmonopol accepteres ikke længere betingelsesløst af medlemmerne. Det er således på denne baggrund, at man må forstå artiklens kritik af eksempelvis de bureaukrati-teoretiske forklaringer på modsætningen mellem ledelse og basis i fagbevægelsen (artiklens s. 32). Forklaringen, som her går på, at denne modsætning kun er et organisatorisk-politisk udtryk for fagbevægelsens modsætningsfyldte integration i kapitalforholdet, ses herved ikke blot at være en logisk konsekvens af en almen afledning af fagforeningsorganiseringen. Det bliver klart, hvorledes modsætningen har udviklet sig historisk og således har udgjort det materielle grundlag for fagforeningsanalysen. (Jvf. artiklens første side, hvor forfatterne henviser til, hvorfor de har måttet konkretisere deres tidligere bestemmelse.)

De venstreintellektuelles organiseringsproblem. For at forstå pointen i artiklens konklusioner omkring spørgsmålet om mulighederne for socialistisk fagforeningsarbejde, er det nødvendigt at specificere subjektet/-erne i en sådan fagforeningsstrategi. Desværre foretager artiklens forfattere ikke selv reelt denne specificering. Det er imidlertid på dette punkt særlig vigtigt at skelne mellem arbejderklassens faktisk historisk udviklede organiseringsformer (her de fagforeningsmæssige) og de venstreintellektuelles fors $\varnothing g$ på at handle politisk. Det drejer sig her om den umiddelbare adskillelse mellem de intellektuelle og arbejderklassen, som den kapitalistiske arbejdsdeling mellem hånds- og åndsarbejde sætter. Vi vil senere i denne kommentar gå nærmere ind på dette problem, og her blot begrænse os til at pege på specifikke træk i den vesttyske studenter- og

4. Se f.eks. Eberhard Schmidt, Ordningsfaktor oder Gegenmacht, suhrkamp 1971, og M. Schumann, m.fl., Am Beispiel der Septemberstreiks- Anfang der Rekonstruktionsperiode der Arbeiterklasse?, Europäische Verlagsanstalt 1971. 
venstrebevægelse, som kan begrunde artiklens manglende specificering af dette spørgsmål.

Vi har ovenfor kort berørt de særlige udviklingsbetingelser, som den fagligt organiserede arbejderbevagelse har fungeret under. Hvad angår den tyske venstre- og studenterbevagelse gør der sig imidlertid ligeledes særlige forhold gældende: Uden her at gå ind på de samfundsmæssige betingelser for dennes udvikling, er det ikke uden betydning at konstatere, at SB (som udgør den organisatoriske ramme, indenfor hvilken den foreliggende analyse er blevet til) udover flertallet af intellektuelle marxister også omfatter socialistiske arbejdere, som er fagligt organiserede i bedriftsråd på forskellige virksomheder. Indenfor SB har der således udfoldet sig omfattende diskussioner mellem arbejderne og de intellektuelle indbyrdes af, hvorledes man teoretisk og praktisk kunne støtte de revolutionære kræfter i striden mellem bedriftsråd og fagforeningsledelse. (sml. Thesen. ., s. 22) Eftersom den tyske venstrebevægelse således faktisk opviser reelle forbindelser mellem socialistiske arbejdere og intellektuelle, bliver det også af denne grund forståeligt, hvorfor forfatterne til nedenstående artikel konkluderer relativt generelt på spørgsmålet om strategien overfor fagforeningerne. »Kommunister og socialister « må søge at realisere deres strategi ved at besætte fagforeningsposterne med venstreorienterede folk. Kravet om den her nævnte skelnen mellem arbejdere og intellektuelle har altså øjensynligt ikke samme $n \phi d v e n d i g e$ relevans, som det klart har i den danske virkelighed.

\section{Et eksempel fra den danske venstrefløjsdebat}

Inden vi tager hul på diskussionen af den teoretiske del af artiklen, vil vi nu kort karakterisere diskussionen om arbejderklassens organiseringsbetingelser, som den har været ført på den danske venstrefløj, for dermed at kunne præcisere de landvindinger og problemer som artikler leverer.

I Kurasje nr. 9 har to karakteristiske synspunkter været præsenteret i form af fortsættelsen af en diskussion mellem Vilhelm Borg og Kjeld Schmidt ${ }^{5}$ - nu videreført mellem Sigurd Jensen og sidstnævnte. Vi vil ikke her forsøge at argumentere for eller imod den eller den anden position, men kort fors $\emptyset \mathrm{ge}$ at karakterisere det udgangspunkt, hvorpå den har været ført og - som en slags henvisning til artiklen - antyde en kritik af dette grundlag. Vi mener at begge positioner har udgangspunkt $\mathrm{i}$ et begreb om en $i$ sit udgangspunkt revolutionar arbejderklasse, der som følge af særlige historiske omstændigheder imidlertid er blevet hæmmet

5. Sigurd Jensen. Politisk uddannelse: dens samfundsmæssige betingelser og dens muligheder og grænser for en politisering af arbejderbevidstheden, Kurasje nr. 9, s. 4-37 og Kjeld Schmidt: Den moderne storindustri og arbejderbevægelsens krise. Antikritik, Kurasje nr. 9 s. 37-53. 
af reformismen. Det problem, der således stiller sig for de to forfattere, (og for store dele af venstrefløjen) er dels at forklare denne 'amputering' og dels at diskutere en strategi for hvordan arbejderklassen mest adækvat frigør sig fra dette historiske reformistiske greb.

For Borg og Jensen må forklaringerne på arbejderklassens afmagt findes i »arbejdernes indskrænkede erfaringshorisont under den store industris fremmedbestemte eller hierarkiske kooperationsform « (Kurasje nr. 9, s. 24). På trods af forsikringer imod den »teknologiske determinisme $«^{6}$ efterlades der (som bl.a. påvist af K. Schmidt) i sidste instans ikke andre forklaringer på arbejderklassens »resignation og afmagtsfølelse efter 1. verdenskrig « (s. 21) end »den begrænsede erfaringsbasis under storindustriel kooperation «.

Dette indhold i positionen træder tydeligt frem når Borg og Jensen skal undersøge den automatiserede produktions kooperationsform. Jensen anfører: »Lad os nu til sidst se på hvor vidt automatiseringen $\mathrm{i}$ industrien skaber forudsætningerne for at overvinde den resignerede bevidsthed om en uforanderlig tilstand.« (s. 29) For det første fremtræder det her klart, at sådanne forudsætninger ikke har eksisteret i storindustrien. Jensen fokuserer nu på den »autonome aktivitet«, som »under automationen åbner muligheden for at de strejkende erkender eller indser, at de sociale fænomener som de førhen har anset for at være uforanderlige lovmæssigheder [...] er [...] i princippet foranderlige forhold.« (s. 32) Nu bliver billedet tydeligt af arbejderklassen som en i sit udgangspunkt revolutionar klasse, der af specifikke periodiske arbejdsprocesforhold har været fremmedgjort. Under den begyndende automation bliver denne arbejderklasse kun tilbageholdt eller undertrykt i sin revolutionære potens af »fagforeningernes konfliktforebyggende virksomhed overfor den daglige klassekamp i virksomhederne, som en konsekvens af den centrale klassekonflikts institutionalisering i dette århundrede« (s. 27) ${ }^{7}$. Med andre ord: arbejdsprocessen (produktionsprocessens stoflige side) sætter forudsætningerne for om den »revolutionære arbejderklasse« resignerer eller ej. Når dette historisk specifikke undertrykkelsesmoment (fremmedgørelsesmoment) ikke er tilstrækkeligt til at forklare den manglende udfoldelse af den revolutionære potens, trækkes de specifikke subjektive organisationsforklaringer ind.

Den teoretiske svigt i denne position består i, at udbytningsforholdet overhovedet ses som et subjektivt enkeltkapitalistisk udbytningsforhold (hierarkiseringen af arbejdsprocessen). Der ses bort fra produktionsprocessen som enhed af arbejds- og valoriseringsproces og dermed fra, at det undertrykkende konstituerende (periodicerende) element er kapitalen som samfundsmassigt vaerdiforhold (uddybes i behandlingen af artiklen).

For Schmidt stiller spørgsmålet sig som nævnt også som 'forklaringer på reformismens sejrsgang efter 1 . verdenskrig'. Schmidt afviser Jensens position

6. »Dette betyder selvfølgelig ikke at arbejdernes adfærd og bevidsthed udelukkende og entydigt bestemmes af arbejdet i den strukturelle kooperation.«, Kurasje nr. 9, s. 24.

7. Her er vi i Kurasje nr. 9 næsten tilbage i fagforstenningstesen: I. Wechselmann og K. Schmidt: Fagforstenningen. Se også Kurasje nr. 2-3. 
som objektivistisk. I stedet hævder Schmidt, at kapitalens subjektive politiske udspil i form af den »Tayloristiske offensiv« (s. 15) overfor arbejderklassen, og organisationernes forrædderi (s. 52) ${ }^{7}$ er den egentlige forklaringsbasis. »Styrkeforholdet mellem klasserne « (kapitalens offensiv og arbejderklassens reformistiske svækklse) bliver dermed det afgørende for, om de revolutionære og altid latente kræfter i arbejderklassen kommer til udfoldelse. Også Schmidt gør herved reformismen til et 'degenerationsproblem', der forklares historisk under henvisning til klassernes politiske styrkeforhold. Strategien bliver dermed entydigt udviklingen af en revolutionær organisering, der kan råde bod på dette for arbejderklassen »ufordelagtige« styrkeforhold og opbygge en effektiv modmagt - altså en partiorganisatorisk modstrategi.

Schmidt reducerer herved forholdet mellem lønarbejde og kapital til et forhold mellem rene klassesubjekter, hvorved kapitalforholdet som objektivt værdiforhold forsvinder fra historiens horisont.

Vi skal ikke her uddybe denne kritik nærmere, men nøjes med at præcisere, at vi generelt mener, at udgangspunktet for begge positioner hviler på abstraktioner i forhold til arbejderklassens faktiske historiske udvikling. De tager udgangspunkt i en 'genuin' revolutionær arbejderklasse, hvis degeneration er affødt af historisk specifikke (residual-) forhold. Dette bliver således deres eneste begrundelse for reformismen. Med dette udgangspunkt i arbejderklassen som en fremmedgjort eller voldført klasse udtrykker de 2 forfattere snarere de venstreintellektuelles politiske organiseringsproblem og forbindelsesproblem end arbejderklassens eget organiseringsproblem. Diskussionen er herved kommet til at dreje sig om, hvordan de venstreintellektuelle fører deres revolutionære bevidsthed ind i arbejderklassen - enten som hos Borg/ Jensen igennem en elitær arbejderoplysning, eller som hos Schmidt igennem en avantgardistisk organisationsløsning.

Ingen af positionerne diskuterer arbejderklassens faktiske historiske interessekamp og således heller ikke de begransninger og illusioner, som kapitalen sætter for en revolutionær radikalisering og gennemskuen af de mystificerede overfladeformer, henholdsvis de muligheder kapitalen leverer for en sådan radikalisering.

$\mathrm{Vi}$ vil nu igennem diskssionen af artiklen argumentere for, at udgangspunktet for den diskussion, der er formuleret ovenfor, må være kapitalforholdet. Da kapitalforholdets historiske udvikling i sig indbefatter arbejderklassens udvikling, må arbejderklassens reproduktionskamp ses som et led heri, og kan ikke betragtes som et isoleret subjektivt erfaringsfelt. Derfor er der her lagt op til en afgørende skelnen mellem, om politiske erfaringer vurderes isoleret i forhold til arbejderklasssens specifikke erfaringer, eller om de vurderes med udgangspunkt i kapitalens historiske udviklingsproces. Med disse pointeringer mener vi selvfølgelig ikke, at de venstreintellektuelles organiserings og forbindelsesproblem er løst. En af forudsætningernnne for at diskutere dette er imidlertid, at problemet om arbejderklassens historiske organisering betingelser er korrekt stillet. Vi vender i slutningen tilbage til dette spørgsmål. 


\section{Kritisk præsentation af artiklen}

Eftersom den foreliggende analyse er udarbejdet som led i en politisk diskussion blandt tyske venstregruppers vurdering af de tyske fagforeninger i forbindelse med spørgsmålet om en socialistisk fagforeningspolitik, vil vi også her først og fremmest vurdere artiklen ud fra spørgsmålet, om forfatterne faktisk når videre end de opfattelser af fagforeningsspørgsmålet, som de kritiserer. (Se artiklen s. 25-28).

Redaktionskollektivet tager afstand fra fortolkninger af klassekampen, som reducerer de teoretiske og politiske problemer ved sådanne fortolkninger til almengørelser af og modelbygninger over hidtidigt indhøstede kamperfaringer, og påpeger med rette disse forkortede analysers begrænsede konsekvenser: strategien udvikles ikke historisk specifikt, og bliver derfor udvendig i forhold til arbejderklassens faktiske situation. Betragtes klassekampen som i overvejende grad, begrænset af styrkeforholdet mellem klasserne, vil en fagforeningspolitik, som baseres herpå, altid kun reproducere klasseforholdet og endda muligvis virke hæmmende på en revolutionær udvikling.

Denne artikels bidrag til en videreudvikling og overskridelse af de hidtidige analyser af arbejderbevægelsens bevidsthed og udviklingsproces falder indenfor 2 områder:

For det første giver dens bestemmelse af fagforeningerne som element i kapitaludviklingen det almene grundlag, som fremstiller muligheden for at forstå, hvorledes fagforeningerne kan udvikle sig til rene kapitalistiske fagforeninger. Dermed bliver teorierne om arbejderklassens 'degenerations-problem' endeligt distanceret. Vi vil nedenfor søge at påvise, hvorledes artiklen altså ikke fremstiller den almene bestemmelse af fagforeningernes $n \phi d v e n d i g h e d$. Det er vores opfattelse, at artiklen indeholder en alvorlig uklarhed på dette spørgsmål. På den ene side taler forfatterne om arbejdernes tvang til at slutte sig sammen i fagforeninger, på den anden side afviser de at give bestemmelsen en almen begrebslogisk status. Gengen en diskussion af fagforeningernes historisk-logiske udviklingsbetingelser vil vi forsøge at påvise en tendens hos forfatterne til at forblive fikseret i den almene afledning.

For det andet implicerer forfatternes udgangspunkt i kapitalens anatomi et materialistisk begreb om reformismen i arbejderbevægelsen. Idet forfatterne tager udgangspunkt »i klassebevægelsen ${ }^{8}$ selv « (artiklens s. 27), forskyder de det felt, indenfor hvilket unders $\emptyset$ gelsen af arbejderbevægelsens $\varnothing$ konomiske og politiske kampe og betingelserne herfor må føres, fra klassekampens subjektive fremtrædelse (som må ses som det materielle grundlag for de kritiserede forestillinger) til det samfundsmaessige forhold mellem lønarbejde og kapital, dvs. til en betragtning af arbejderbevægelsens udvikling som et element i kapitalens udviklingsproces. Det betyder, at deres begreb om reformismen ikke udvikles på

8. Hvad dette begreb implicerer for forfatterne fremgår af artiklens s. x-x. Den her antydede bestemmelse lider under samme teoretiske uklarhed, som vi senere vil vise gælder for resten af artiklen. 
basis af en isoleret betragtning på arbejderklassen. Derimod forstås denne reformisme som en nødvendig bevidsthedsform hos arbejderklassen, sådan som den kan bestemmes strukturelt i forbindelse med overfladeformerne i det borgerlige samfund. Dette er en teoretisk landvinding, der vil kunne udvikle og kvalificere analyserne af udviklingen i arbejderklassens kamp- og organiseringsformer.

Det må nu være væsentligt på baggrund af artiklens eget udgangspunkt at undersøge, hvorvidt forfatterne selv lever op til kravet om at »gå ud fra analysen af klassemodsætningens udviklingsniveau såvel som dens -retning « (s. 27). Forfatterne fastholder overfor de tidligere refererede historisk løsrevne analyser, at »det borgerlige samfunds anatomi, der er afdækket i den marxske teori, må være det teoretiske grundlag... (s. 27).

Heri kan vi principielt kun erklære os enige. Imidlertid mener vi, som nævnt, at der i artiklen er en tendens til at fiksere fagforeningernes konstitutionsproces i en abstrakt-almen bestemmelse, hvilket ikke blot får konsekvenser for deres politiske konklusioner vedrørende mulighederne for socialistisk fagforeningsarbejde (se dette afsnits afslutning); men det fastlåser endvidere analysen i en reproduktion af adskillelsen mellem den almene bestemmelse og den historiske analyse. (Jvf. her de almene bestemmelser i artiklens 1. del overfor den historiske fremstilling af det aktuelle forhold mellem lønarbejde/kapital og fagforeningspolitik i BRD i artiklens 2. del.).

Vender vi os nu mod den strukturelle bestemmelse af den fagforeningsmæssige organisering af arbejderklassen, fremgår det eksplicit, at forfatterne mener at have konkretiseret den begrebslige bestemmelse af fagforeningerne, i forhold til deres bidrag i Prokla 2. I sidstnævnte artikel udvikles fagforeningernes modsætningsfuldte bestemthed som det forhold, at arbejdernes organisering på den ene side er integreret i det kapitalistiske lønsystem, og på den anden side som organisationer for lønarbejdets modsætning til kapitalen »samtidig skal frisætte klassekampens potenser « (se også artiklens note 1). I nærværende artikel foretages nu en uddybning af denne bestemmelse: som refereret analyseres her nærmere først konkurrencen mellem de enkeltstående isolerede arbejdere indbyrdes. Denne konkurrence fremtvinger arbejdernes sammenslutning for at ophæve de skranker for den individuelle reproduktion, som arbejdernes isolerede stilling overfor kapitalen sætter. Denne tvang bestemmes overhovedet med henvisning til kapitalen som koncentreret samfundsmassig magt (s. 29): Kapitalisten er i besiddelse af produktionsmidlerne, arbejderne af deres arbejdskraft i vareform, hvorfor kapitalisten gennem sin tilegnelse af den særlige brugsværdi arbejdskraft har muligheden for at udplyndre arbejderne efter de af ham satte betingelser. Som konkurrencemiddel heroverfor har arbejderne kun deres antal. På grundlag heraf bestemmes nu fagforeningernes funktion som den at sikre arbejderne en ækvivalent for salget af deres arbejdskraft (en »retfærdig arbejdspris«). Denne funktion, som er strukturelt forbundet med bytteforholdets fordrejede overfladeformer (ækvivalentbyttets skin), er det materielle grundlag for den fagforeningsmæssige reformisme. Fagforenings-bestemmelsen konkretiseres imidlertid herefter yderligere: (afs. 1.5) nu betragtes 
ikke blot de enkeltstående arbejderes indbyrdes konkurrence, men endvidere de forskellige arbejderlags fors $\emptyset \mathrm{g}$ på at forbedre deres salgsbetingelser over for kapitalen gennem deres afsondring fra andre arbejdere. Dette forklares som en konsekvens af, at enkeltkapitalerne i deres konkurrence opnår forskellige 'positioner', hvilket skaber grundlag for en differentiering mellem forskellige arbejderlag i arbejderklassen. (F.eks. kvalificerede over for ukvalificerede arbejdere). Eksistensen af disse gruppers sammenslutning i standsmæssige fagforeninger må således forstås som en organisatorisk reproduktion af den af kapitalen skabte differentiering af arbejderklassen.

Men hvilken form for konkretisering er der nu her tale om? Når udgangspunktet tages i det udfoldede bytteforhold mellem kapital og arbejde, må en bestemmelse af fagforeningerne, som vil prætendere at være funderet i kapitalens (eller værdilovens) modsigelsesfulde udfoldelsesproces, også medreflektere de bevægelser, som netop opløser bytteforholdets skin (det skin, at arbejderen fremtræder som ligestillet produktionsfaktor ved siden af faktorerne kapital og jord). Hvad er det nemlig, som gør ækvivalentudvekslingen til realt skin? Her kan det ikke være tilstrækkeligt abstrakt at henvise til, at »kapitalen fremstiller koncentreret samfundsmæssisig magt« (s. 29) som det afgørende væsensforhold. Artiklen opnår ved dens almene formlogiske tilgang kun at sammenknytte kapitalens cirkulations- og produktionssfære formelt. Således analyseres arbejdernes indbyrdes konkurrerende uformidlet til de modsigelser i kapitalens udvikling, som er grundlaget for denne konkurrence. Konkurrencen analyseres herved uafhængigt af den særlige beskaffenhed, som arbejdskraften har, når den underlægges kapitalen. De former, som arbejdernes indbyrdes konkurrence antager på samfundets overflade - begrundet i cirkulationsaktens løsrivelse fra produktionsprocessen -, kan ikke i sig selv danne grundlag for bestemmelsen af fagforenings-sammenslutningens $n \phi d v e n d i g h e d$ (allerh $\varnothing$ jst af dennes mulighed). Det synes imidlertid at være tilfældet i artiklen. For os at se hænger det sammen med, at forfatterne ikke medreflekterer de skranker i den historiske udviklingsproces, som kapitalen fors $\varnothing$ ger at overvinde gennem ændringer i produktionsbetingelserne for dens fortsatte akkumulation. Dette må indføres for at afdække den reale gennembrydning af cirkulationssfarens skin af lige ækvivalentbytte til fordel for den virkeligt eksisterende ulighed.

Inddragelsen heraf ville eksempelvis implicere en fremstilling af de tendenser, som nødvendigg ør, at kapitalen udvikler grupper af arbejdere med særlige kvalifikationer. Når det således flot postuleres, at enkeltkapitalernes konkurrence medfører en differentiering i arbejderklassen (s. 32), mener vi ligeledes, at de almene bestemmelser, som analysen opererer med, begrænser holdbarheden i dens resultater. Således ser forfatterne på det omtalte sted bort fra kapitalens almene historiske tendens til en samtidig homogenisering og ensliggфrelse af arbejderne. Denne pointe er væsenlig at indføre, når fagforeningsorganisationernes historisk sarlige fremtrædelsesformer skal analyseres, og mulighederne for en forvandling af disse »til instrumenter for den almene klassekamp mod kapitalen« (s. 34) skal diskuteres. 
Denne mangel i afledningen, som derfor ikke tager form af en dobbeltbestemmelse, mener vi er udtryk for, at der ses bort fra det modsatningsfyldte i kapitalens udviklingsproces. Den ensidigt formelle betragtning på ækvivalentudvekslingen implicerer således en tendens til, at den underlæggelsesproces, hvorigennem kapitalen tilegner sig merarbejdet, bortnegligeres. Derved udelukkes det forhold, at kapitalen historisk gennem denne proces, som et led i dens samfundsmæssiggørende tendens, sætter arbejdet stadig mere abstrakt. Tidligere (i note 1) har forfatterne anført, at fagforeningerne som organisatorisk sammenslutning af arbejdernes modsætning til kapitalen angiver muligheden for eksistensen af overskridende elementer i denne organisering. Den refererede ensidighed i forfatternes bestemmelse af fagforeningernes udvikling kommer her til udtryk i, at denne mulighed falder bort i løbet af analysen. Af denne grund bliver deres konklusion om at gøre fagforeningerne til 'bevægelsesform for klassekampen' også postulatorisk og fremtræder som en påhæftet politisk strategi uden reel forbindelse til den $\phi$ konomiske bestemmelse af fagforeningernes funktion. Som følge af fagforeningernes integration i det kapitalistiske system, konkluderes det altså, at kommunisters og socialisters strategi overfor fagforeningerne må »dreje sig om at give udviklingen af klassemodsigelsen og af klassekampen en bevægelsesform i fagforeningen, at udvikle fagforeningsorganisationerne til instrumenter i klassekampen, overhovedet at organisere arbejdernes klassemodstand formidlet over fagforeningen.« (s. 35). Omend det advares mod, at denne strategi gøres til genstand for illusioner om, at det skulle være muligt at forandre fagforeningerne til revolutionære organisationer, ligger der dog i strategiens uklare formulering en mulighed for, at den tages til indtægt for kravet om at forvandle fagforeningerne til autonome kamp- organisationer (hvilket forfatterne selv kritiserer »express « - redaktionskollektivet for. Se 2. del og artiklens note 3.) Begrundelsen for konklusionen savnes i analysen, hvorfor formuleringen i note $1 \mathrm{om}$ de overskridende elementer i fagforeningsdannelsen fremstår rent postulativt.

Med andre ord: konsekvenserne af at ville forsøge sig med konkrete politiske udsagn på baggrund af abstrakt-almene bestemmelser, viser sig i artiklen som en uklarhed i diskussionen af betingelserne for at overskride den strukturelt bestemte fagforeningsreformisme. Ganske vist holder artiklen fast ved, at udgangspunktet også for denne diskussion må være kapitalbevægelsen: »Dermed finder den reformistiske bevidsthed dog også en skranke i tilspidsningen af konflikterne i akkumulationsprocessen i den skærpede udbytning gennem kapitalen (arbejdsløshed, løntryk...) og i undertrykkelsen gennem det statslige repressionsapparat «. (s. 38). Heri antydes, at fagforeningernes begrænsning er kapitalbevagelsens grænser og kriseskranker, som derved bliver det grundlag, hvorpå en overskridelse af den rent fagforeningsmæssige kamp kan finde sted. Hvordan kan fagforeningerne så samtidig være »bevægelsesform for klassekampen«?

Tilsyneladende ender forfatterne $\mathrm{i}$ en abstrakt bestemmelse af betingelserne for arbejderklassens politiske emancipation ved at udelade diskussionen om forholdet mellem fagforeningsorganisering og partiorganisering. Det er ganske vist 
korrekt, at dette spørgsmål ikke lader sig diskutere alment - og dermed falder uden for fremstillingsrammen - men konklusionen bliver indskrænket til, at fagforeningerne i krisen, som anført, tvinges til at satse på at opretholde lønarbejdet som lønarbejde »inden for det kapitalistiske samfund «.

Den eneste strategiske konklusion, der således kan trækkes umiddelbart, er den, at arbejderklassen igennem sin reproduktionskamp - som denne betinges af kapitalens bevægelse - således er $i$ stand til at udvikle revolutionære organiseringer. Den politisk strategiske pointe, som gør artiklen frugtbar, ligger altså mere i udgangspunktet for diskussionen af reformismen end det ligger i selve de politiske konklusioner. Når forfatterne imidlertid ikke kommer meget længere, mener vi, det også her hænger sammen med den måde, som forfatterne nærmer sig de almene bestemmelser på (ved at adskille dem skarpt fra de historiske elementer, der ligger i dem).

Til sidst vil vi kort problematisere den uklare position, som forfatterne foretager deres politiske diskussion (med »express «-folkene) ud fra. Forfatterne anvender som nævnt ingen andre præciseringer end »kommunisters og socialisters opgaver i forhold til fagforeningerne.... (vores understregning). I forhold til denne politiske diskussion savnes der således klarhed over, hvad der er socialisters basis for at operere politisk i forhold til fagforeningerne. Dette rejser spørgsmålet om de venstreintellektuelles udgangspunkt for at forholde sig til arbejderklassens aktuelle kamp.

Relevansen af dette spørgsmål er måske særlig tydelig i forhold til den danske revolutionære venstrefløj, (den venstreintellektuelle), der som tidligere nævnt ikke har skelnet imellem dens eget forbindelsesproblem og arbejderklassens organiseringsproblem. Dette resulterer i, at der efterlades et tomrum, hvor de intellektuelle socialister eksisterer uden andet end en rent organisatorisk basis. Som ovenfor anført stiller situationen i »Sozialistisches Büro« måske de tyske venstreintellektuelle anderledes end de danske.

De venstreintellektuelles forbindelsesproblem har hidtil i DK været »løst« ved selvforståelser som f.eks. »de intellektuelle må stille sig på arbejderklassens revolutionære standpunkt « og "problemet er de revolutionære gruppers forankringsbestrabelser «. Her kommer det til udtryk, hvorledes man har opereret med et helt udvendigt forhold mellem de intellektuelle og arbejderklassen. Dette udvendige forhold reproduceres tendentielt i de danske primærorganisationer som et udvendigt forhold mellem revolutionær partiorganisation og arbejderklassens egen subjektive konstituering.

Overfor denne selvforståelse af de intellektuelle som slet og ret politisk revolutionære subjekter, mener vi at en historisk bestemmelse af de intellektuelles samfundsmæssige placering er påkrævet. Med udviklingen i den samfundsmæssige arbejdsdeling har de intellektuelle udskildt sig som åndsarbejdere, der i forhold til arbejderklassen har optrådt på borgerskabets side. Dette klassetilhørsforhold har været begrundet i deres objektive stilling i den samfundsmæssige klassedeling. 
Aktuelt er der ved at ske udviklinger i dette tilhørsforhold. Bl.a. krisen i uddannelsessystemet og videnskaberne har efterladt begyndende organiserede bevægelser ${ }^{9}$ af socialistisk tilsnit iblandt studenterne og begyndende organiserede politiske opgør med de borgerlige videnskaber, som de intellektuelle har været og er bærere af.

Men det er vigtigt at forstå dette som en politisk subjektiv overskridelse af de objektive funktioner hos de intellektuelle, idet deres adskillelse fra arbejderklassen, som følge af den fundamentale adskillelse af hånds- og åndsarbejdet, stadig består. Denne adskillelse betyder på den ene side, at de intellektuelles samfundsmæssige placering ikke i sig selv nærmer sig en med arbejderklassen solidarisk placering, og på den anden side at 'forbindelsesproblemet' mellem venstreintellektuelle og arbejderklassen således fortsat består.

Hvordan kan den nuværende socialistiske bevægelse blandt de intellektuelle da forholde sig til arbejderklassens aktuelle kamp (uden at basere sig på et fiktivt begreb om en nutidig revolutionær arbejderklasse)? Spørgsmålet må bl.a. besvares med udgangspunkt i det særlige samfundsmæssige radikaliseringsgrundlag som eksisterer for bevagelsen blandt de intellektuelle, nemlig afsløringen af deres egne samfundsmæssige funktioner overfor arbejderklassen (bærere af den borgerlige videnskab) som 'bevarende' i det borgerlige samfund. Denne afsløring rækker videre end en ren teoretisk kritik og indbefatter de praktiske udtryk for videnskaberne. Dette praktiske udtryk er imidlertid videnskaberne som anvendelige i det borgerlige samfunds reproduktion. Hermed knytter de venstreintellektuelles radikaliseringsgrundlag indholdsmaessigt an til arbejderklassens reproduktionskamp, og opgøret med/afsløringen af, 'åndsarbejderfunktionerne' kan i sit sigte udvikles parallelt med den faktiske udvikling i arbejderklassens kampformer.

De venstreintellektuelle kan således, på trods af en objektiv adskillelse fra arbejderklassens kamp, forholde sig konkret indholdsmæssigt til denne. Formidlingen ligger i det nævnte forhold, nemlig at deres specifikke funktioner står i et indre forhold til den kapitalistiske produktions- og reproduktionsproces. Hermed gives der imidlertid ikke længere almene løsninger på 'forbindelsesproblemet', men derimod 'løsninger' der må udvikles specifikt omkring de særlige samfundsmæssige funktioner, som forskellige grupper af intellektuelle er bærere af.

Vi mener således, at forbindelsesproblemet ikke kan forklares alene med henvisninger til 'et lavt udviklingsniveau i klassekampen' eller - som en anden variant - 'det for lavt udviklede teoretisk videnskabelige niveau blandt de venstreintellektuelle' og de strategier som følger heraf. Derimod må vi hævde at de socialistiske intellektuelle må forholde sig til arbejderklassens faktiske kamp og udviklingsretning på grundlag af en erkendelse af de særlige indre sammenhænge, der består imellem de intellektuelles samfundsmæssige funktion og arbejderklassens reproduktionsbetingelser.

9. Dette står i modsætning til de individuelle intellektuelle socialister, som altid har eksisteret blandt kapitalismens åndsarbejdere. 


\title{
Afslutning
}

Den diskussion, vi her har ført omkring fagforenings-artiklen, er som nævnt stærkt begrænset af denne 1. del's almene karakter. Ikke desto mindre har vi fundet det rimeligt at fremdrage dens væsentligste fortjenester, for så vidt de kan bidrage til en frugtbar videreudvikling.

Artiklens centrale pointe ligger således i dens udgangspunkt for kritikken af reformismen i arbejderbevægelsen; nemlig et udgangspunkt i Marx' kategorielle fremstilling af det kapitalistiske samfunds anatomi. Reformismen bestemmes her som et i det borgerlige samfunds overflade materielt funderet element - og ikke blot som et politisk og teoretisk forfald. Hermed leveres et tiltrængt teoretisk grundlag for en materialistisk forståelse af »arbejderbevægelses historie« og en problematisering af dette emneområde som et isoleret arbejdsfelt.

Vi har imidlertid kritiseret denne teoretiske fortjeneste for stadig at operere med en sådan forståelse af den kategorielle fremstilling, som tendentielt amputerer forbindelsen til en historisk fremstilling. Artiklens fremstilling af kapitalens logik som grundlag for fagforenings- og reformisme-bestemmelsen har en tendens til at udradere det kritisk historiske element i kategorierne. Således står produktion (kapitalen som koncentreret samfundsmæssig magt) og cirkulation (de ækvivalente k $\varnothing \mathrm{b}$ og salg af arbejdskraft) som rene formkategorier overfor hinanden, og ikke som historisk reale sfarer, der antager ganske særlige fremtrædelsesformer i deres underordning under kapitalen. Herved opstår der en tendens til at det kritiske aspekt i Marx' fremstilling falder væk, og, det bliver derfor, som vi har forsøgt at vise, vanskeligt at knytte den i sit udgangspunkt 'rigtige' reformisme-bestemmelse an til diskussionen af udviklingsbetingelserne for overskridende, revolutionære positioner i arbejderbevægelsen.

\begin{abstract}
Proletarische Front. Gruppe Westdeutscher Kommunisten: Imperialismen i dag. 304 sider. 45 kroner. PF-GWK forsøger at vise, hvordan den nuværende overakkumulationskrise i de imperialistiske centre markerer afslutningen på 3. fase i arbejdets reelle subsumtion (dvs. underordningens form) under kapitalen. Men krisen i forholdet mellem centre og periferi er derimod karakteriseret ved afslutningen på en imperialistisk fase, hvor det såkaldte "ulige bytte « har været dominerende princip, og hvor det eneste imperialistiske svar i dag er oprettelsen af en række relativt selvstændige, nye akkumulationscenter.
\end{abstract}

\section{Forlaget MODTRYK}

Anholtsgade 4, 8000 Århus C.

Postgiro 5216478 . Telefon (06) 127912 